\title{
OS MILITARES E A ORDEM CONSTITUCIONAL REPUBLICANA: DE 1898 A 1964
}

\author{
Romeu Costa Ribeiro Bastos \\ Maria Elizabeth Guimarães Teixeira Rocha
}

\section{RESUMO}

No presente artigo busca-se avaliar o papel dos militares na ordem constitucional brasileira, durante o período compreendido entre a proclamação da República e o golpe de 1964 . Neste sentido serão analisadas as inúmeras fases de irrendentismo e revoltas militares ocorridas ao longo do processo histórico, bem como a ação intervencionista das Forças Armadas, que sempre atuaram institucionalmente como árbitros - legais ou supra legais entre as elites econômicas, sociais e políticas no interior do Estado Nacional.

Palavras-Chaves: Militares; ordem constitucional; república; Brasil. 
A análise das intervenções castrenses ao longo da história republicana brasileira demanda, a priori, uma avaliação sobre o papel dos militares no Estado, na política e sua interação com a sociedade civil.

O conceito de profissionalização nas Forças Armadas surgiu como resposta à necessidade de contextualizar sua atuação a partir de um referencial sociológico que a situasse comparativamente diante de outros grupos funcionais no interior do sistema social. Com base nessa formulação, tornou-se possível definir a competência profissional militar perante o Estado e a sociedade, a despeito da dificuldade em compatibilizar a oposição teórica entre ação militar e política.

De fato, o relacionamento do Estado com as Forças Armadas não se reduz à mera relação profissional-cliente mas a uma efetiva relação de poder, uma vez que, as Forças Armadas, não atuam apenas como profissionais, detentoras que são de autoridade que lhes foi constitucionalmente outorgada.

Tal competência encontra-se intrinsecamente vinculada ao papel dos militares e seu inter-relacionamento com a sociedade civil, cujo aspecto fundamental traduz-se na tensão potencial da necessidade de os governantes manterem, por um lado, uma força armada como instrumento da política e da ordem interna e, garantirem, por outro, que ela não usurpe os aparelhos do Estado ${ }^{2}$

Nesta linha teórica, quatro modelos explicativos sistematizados por Janowitz ${ }^{3}$ são apontados como definidores da relação civil-militar: o aristocrático, o democrático, o totalitário e o profissional.

O modelo aristocrático corresponde à estrutura das elites. Sua essência reside no fato de que os valores sociais e os interesses materiais das elites militares e políticas numa sociedade aristocrática são naturalmente convergentes. A base do recrutamento da

1 Frase atribuída a um oficial da República Dominicana. In: LOWENTAL, Abraham F., Armies and Politics in Latin America, New York, Holmes \& Meier Publishers, Inc., 1976, p.3.

2 STEPAN, Alfred, Os Militares na Política, Rio de Janeiro, Ed. Arte Nova, 1975, p. 46.

3 JANOWITZ, Morris, Military Institutions and Coercion in Developing Countries, Chicago, University of Chicago Press, 1977, pp. 187 et seq. 
oficialidade, que se define como aristocrata e não castrense, provém da casta civil assegurando, desta forma, a estabilidade do sistema político.

O modelo democrático, caracterizado pela diferenciação entre as elites civil, política e militar, impõe o afastamento deliberado das Forças Armadas da esfera pública decisória, face ao reconhecimento de que, ao menos no plano ideal, o oficial é um profissional apolítico, a serviço do Estado e subordinado às regras e normas legais.

Quanto aos modelos totalitário e profissional, atribuem alto valor à força militar e à especialização. No primeiro, o controle civil é assegurado por meio da seleção política dos chefes militares e reforçado pela infiltração de membros do partido único e pela ação da polícia secreta, em razão da impossibilidade da coincidência social das elites. No segundo, efetiva-se o controle, não por meio da convergência de interesses mas, pela tolerância dos civis para com o desenvolvimento autônomo da influência militar. Huntington, seu principal teórico, sustenta que a busca de objetivos militares profissionais tende a manter as Forças Armadas dentro de sua esfera de atuação.

Outros sistemas podem, ainda, ser citados, como o ditatorial e o moderador, este último especialmente relevante, por nele se encontrar a formulação teórico-explicativa para a atuação das Forças Armadas no movimento irrompido em 1964, à semelhança do ocorrido durante a monarquia, quando o Imperador detinha poderes "constitucionais especiais” para intervir nas crises políticas em épocas de impasse.

Descrito e sistematizado por Alfred Stepan ${ }^{4}$, os axiomas analíticos do modelo moderador ou de arbitragem, podem ser assim relacionados:

- Todos os principais protagonistas políticos procuram cooptar os militares, admitindo-se como regra a politização das Forças Armadas;

- Os militares são politicamente heterogêneos, mas procuram manter um grau de unidade institucional;

- A cúpula política garante legitimidade aos militares, sob certas circunstâncias, para atuarem como moderadores do processo institucional, controlando o Poder Executivo, ou mesmo evitando a ruptura do sistema, quando envolve uma mobilização maciça de novos grupos anteriormente excluídos;

4 STEPAN, Alfred, op. cit, pp. 32 et seq. 
- A sustentação dos militares politicamente heterogêneos pelas elites civis facilita a formação de uma coalizão golpista vencedora. Inversamente, a ausência de tal apoio, impede sua consolidação;

- A formalização de um "pacto" tácito entre civis e militares legitimando a intervenção armada no processo político nacional e o controle temporário do Estado, por um período determinado.

Ora, tomado genericamente, este valor-congruência resulta na socialização civil-militar, exemplarmente ilustrada pela doutrina desenvolvimentista, em sintonia com o projeto de grupos parlamentares. A condescendência social e intelectual dos oficiais militares em relação aos civis possibilita a cooptação e a contínua liderança civil, que visa restabelecer o equilíbrio político e "corrigir" a autoridade de direito e a representação nacional, quando estas entram em coalizão com as forças reais ou as autoridades de fato.

É o chamado "intervencionismo patológico", por meio do qual os civis confiam aos militares o desempenho de um papel moderador, em determinados momentos históricos, para "recompor" a vida política nacional ${ }^{5}$.

5 STEPAN, Alfred, op. cit., p. 51.

Neste ponto, cumpre abordar as várias teorias acerca da intervenção dos militares na política, adequandoas ao contexto nacional, a fim de que sua transculturação não provoque distorções ou interpretações equivocadas, posto a maior parte delas, terem sido formuladas utilizando conceitos e noções paradigmáticas aplicáveis ao Hemisfério Norte. José Num, The midlle class military coup. In: The politics of conformity in Latin América, editado por Cláudio Veliz, London, Oxford University, 1970, ao examinar o tema, concentra sua investigação na hipótese de a intervenção das Forças Armadas resultar dos valores e origem social dos militares. Isto porque, os Exércitos sul-americanos recrutando seus oficiais no seio da classe média, os constituiriam em defensores dos interesses daquela classe, a sua classe. Mais, seria a própria classe média que instigaria os militares a intervirem no processo político a exemplo das grandes mobilizações anteriores ao golpe de 1964. Criticando a posição de serem as classes médias heterogêneas e divididas, Alfred Stepan questiona a viabilidade das Forças Armadas em representá-las politicamente. Stepan observa, ao analisar o golpe de 1964, que os acontecimentos subseqüentes, vg: a extinção dos partidos políticos, a intervenção nas Universidades, as restrições às liberdades civis, dentre outras violações à ordem democrática, atacaram frontalmente as instituições representativas daquele segmento social, daí sua violenta oposição ao governo militar. Samuel Huntington, In: The soldier and the state: the theory and politics of civil-military relations, Cambridge, Mass, Harvard University, 1957, por seu turno, sustenta que a verdadeira causa das intervenções não é militar, mas política; elas não refletem as características sociais e organizacionais do establishment militar, mas a estrutura política-institucional da sociedade. Segundo ele, o processo de modernização cria novos atores políticos - classe média, trabalhadores e camponeses - que exercem pressões e demandas sobre o sistema político. Quando tais demandas e pressões tornam-se superiores à capacidade de absorção do Estado, inviabilizam-se as soluções para dirimir os conflitos. A troca de fases no processo de modernização cria, portanto, uma desordem institucional, e os militares são chamados a intervir para restabelecer o status quo dominante. Por outras palavras, eles serviriam de escudo protetor ao regime, potencialmente ameaçado pelas classes subalternas.

Na interpretação de Samuel Finer, In: The military in politics of today in comparative government, editado por Jean Blondel, Nova York, The Macmillan Press, 1982, a intervenção militar é concebida como resultado 


\subsection{AS INTERVENÇÕES MILITARES E A REPÚBLICA}

\subsubsection{As raízes da crise}

A intervenção militar em 1964 assumiu, efetivamente, a função ideológica de arbitragem ao proteger a burguesia e conter o avanço das forças populares diante da crise institucional. O modelo moderador, porém, se romperia com a implantação de um Projeto Militar gestado ao longo das várias décadas do período republicano ${ }^{6}$.

A história noticia a intervenção política das Forças Armadas a partir da Proclamação da República. Retrocedendo ao regime imperial, a vitória brasileira na Guerra da Tríplice Aliança, faria o Exército emergir como uma força capaz de mudar os rumos políticos da Nação, recrudescendo o ideal republicano.

A geração de Caxias e Osório, forjada nos campos de batalha do Paraguai, seria sucedida por oficiais que não guardavam sentimento de lealdade para com o monarca.

da vontade política da sociedade que a motivou, como também, pelo desejo implícito das Forças Armadas em defender a soberania nacional.

Por fim, Guilhermo O'Donnell, In: Modernización y autoritarismo, Buenos Aires, Paidos, 1972, desenvolveu a interessante teoria da transição do governo populista para o burocrático-autoritário com base em justificativas econômicas. Três tipos de sistemas políticos são identificados: o oligárquico, o populista e o burocrático-autoritário. No oligárquico, a competição política é limitada; a elite do setor de exportação de produtos primários controla o Estado. No populista, há uma coligação entre as elites industriais e o setor popular urbano. A principal meta do sistema é expandir os meios de produção e encorajar as massas a consumi-los. No burocrático-autoritário, os atores políticos são os tecnocratas civis e militares. A participação popular é eliminada em nome de uma industrialização avançada. A passagem de um sistema para outro obedece a uma seqüência histórica, resultado do processo de industrialização e da mudança na estrutura social, só se fazendo possível por força de uma intervenção militar.

6 O positivismo retirou o caráter profissionalizante da corporação e envolveu os militares nas questões sociais e políticas que agitaram o Brasil Imperial. Seus ideais eram a abolição do regime escravagista, a laicização do poder temporal da autoridade espiritual, a República, dentre reivindicações outras. A propósito de tais discussões, Teixeira Mendes num folheto intitulado Abolicionismo e Clericalismo, escreveria no ano de 1888:

"A respeito do Sr. D. Pedro II observaremos que é bem triste defesa para um chefe de Estado o dizer-se que o amor do poder o fez co-participar no suplício dos seus concidadãos. Nunca fizemos de nenhum dos ministros de sua majestade um grande homem. Até hoje só conhecemos um verdadeiro estadista na nossa pátria, e foi o velho José Bonifácio, cuja influência a Monarquia inutilizou. E nem admira que aconteça; porque apoiado em uma constituição, que lhe permitia transformar-se legalmente em um ditador digno e firmado sobretudo nos nossos antecedentes históricos que lhe asseguravam o ascendente do poder central, o Sr. D. Pedro II só soube tornar-se o chefe da oligarquia escravista, ou o que é o mesmo, dos nossos partidos constitucionais.” Apud: OLIVEIRA FREIRE, Felisbelo de, História Constitucional da República dos Estados Unidos do Brasil, Brasília, Editora Universidade de Brasília, 1983, vol.43, pp. 354-355. Ao cabo, tratava-se de uma verdadeira doutrina anti-militarista que sugeria como solução para os problemas das Forças Armadas nacionais o licenciamento geral das tropas e sua substituição pela gendarmeria. Nas palavras de Oliveira Torres, "um militar positivista teria de se envergonhar da farda como Benjamim Constant (...), ou então ser um mau positivista e passar o dia inteiro a trair os postulados de sua fé. Ficaram todos diante de um dilema terrível: ou ser um mau soldado ou ser mau positivista. Acabaram muitas vezes por serem maus soldados, tornando-se naquela estranha e contraditória concepção do cidadão fardado.” OLIVEIRA TORRES, João Camilo de, O Positivismo no Brasil, Petrópolis - Rio de Janeiro - São Paulo, Vozes, 1943, pp.272-273. 
Some-se a isso, a visão patriarcal da época, temente à possibilidade do sucessor do trono ser uma mulher, casada com um estrangeiro que sobre ela exercia grande influência ${ }^{7}$. Conturbava, ademais, o cenário político nacional, a agitação provocada nos quartéis pelas idéias de Benjamin Constant e a teoria positivista do soldado-cidadão ou cidadãosuniformizados, segundo a qual os militares estavam destinados a serem os civilizadores da sociedade brasileira.

O terreno estava propício à primeira grande intervenção militar no Brasil e, as Forças Armadas, tornar-se-iam, efetivamente, as fundadoras da novel República, restando claro a lacuna deixada pela sociedade civil, despreparada para conduzir e defender o Estado Democrático $^{8}$. As forças heterogêneas que apoiaram o movimento republicano incluíam desde os republicanos autênticos,aos monarquistas escravagistas antagonizados com o regime após a abolição. É certo, contudo, ter faltado igualmente aos militares um projeto de governo, imbuídos que estavam, apenas, do ideário salvacionista. A Proclamação da República conscientizara o Exército de sua importância institucional - num processo que se iniciou a partir da Guerra do Paraguai - corroborando a crença da superioridade moral militar sobre a civil. A conseqüência imediata foi a politização das Forças Armadas, constatada pelos vários oficiais nomeados governadores de Estado e eleitos para o Parlamento. A parcela de gastos militares aumentou, mas as violentas lutas internas havidas neste período exporia a organização militar à atuação dos grupos externos, minando a tentativa de implantação de um projeto endógeno.

Após o segundo governo militar consecutivo, os civis alçaram ao poder buscando implantar uma Nova Ordem Civilista ${ }^{9}$. A estratégia adotada por Prudente de

7 O Exército na História do Brasil, Rio de Janeiro, Biblioteca do Exército Ed. 1998, V.3, p.12.

8 Joaquim Nabuco descreveria o início da República com as seguintes palavras: "No dia em que se proclamou a República, podia-se perceber que a nação queria um governo militar para manter a unidade, porque o espírito militar prevalecia de um canto a outro do País, vale dizer, tinha amplitude nacional.”Apud: HAYES, Robert A, Nação Armada - A mística militar brasileira , tradução de Delcy A. Doubrawa, Rio de Janeiro, Biblioteca do Exército, 1991, p.77.

Nas disposições transitórias da Constituição de 1891, previu-se a eleição indireta para o primeiro Presidente da República, pois o povo não estava preparado para o voto livre. In: O Exército na História do Brasil, op.cit., p. 12.

${ }^{9}$ O liberalismo político oligárquico, discriminatório, excludente e antimilitarista, teria na Campanha Civilista, sua maior expressão. A Campanha de 1910, conduzida por Ruy Barbosa, trazia como programa de governo as idéias e princípios do “liberalismo adaptado” pela oligarquia hegemônica. “As oligarquias souberam compreender que as tendências nacionalistas e putschistas dos militares poderiam ser postas a serviço de uma política anti-oligárquica. Tal sentimento era compartilhado desde a Proclamação da República e exprimia o medo de que as intervenções militares no processo político nacional acabassem por escapar do controle das 
Morais foi enfraquecer o poderio das Forças Armadas realizando cortes no orçamento, o que acarretaria a falta de materiais e equipamentos, atingindo de modo contundente a formação profissional dos oficiais. A consecução de tal objetivo, explica o fracasso retumbante das expedições de Canudos e põe à mostra a estagnação provocada pela doutrina do soldado-cidadão que impediu a modernização da Instituição e o florescimento de um pensamento militar autóctone.

Um fato, no entanto, abalaria esta estrutura estamental. Durante a presidência do Marechal Hermes da Fonseca, um grupo de jovens oficiais enviados para estagiar junto ao Exército Alemão, havia retornado ao Brasil com novas idéias e desencadearia uma campanha pelo aperfeiçoamento profissional da Arma. Eram os chamados Jovens Turcos ${ }^{10}$, que propugnavam só poder o Exército desempenhar sua missão de defesa externa, com uma força efetivamente profissional e apolítica.

A idéia da despolitização agradou as classes políticas, ciosas de uma oportunidade para afastar os militares do poder decisório estatal, mas, a despeito da ênfase no profissionalismo, o sentimento de intervenção armada não fora sepultado. A necessidade de substituir o sistema de governo corrupto - articulada desde de 1880 - reviveria em 1920 quando os tenentes, rebelando-se contra Arthur Bernardes, iniciariam o ciclo das intervenções militares que só terminaria em 1964.

\subsubsection{As crises constitucionais}

a. O período de 1920 a 1930

A década de 20 seria marcada por um clima de turbulência e insatisfação social, bem como por transformações significativas na Ordem Internacional.

classes oligárquicas. Em outras palavras, elas pressentiam que o grupo militar poderia, futuramente, intervir em prol das aspirações políticas voltadas para a industrialização. Isto explica o fato de as oligarquias, ao longo de toda a Primeira República, terem se constituído em porta-vozes do "civilismo", propugnando a permanência dos soldados na caserna” In: ROCHA, Maria Elizabeth Guimarães Teixeira, O Processo Político no Brasil. Estado e Classes Sociais, Belo Horizonte, Del Rey, 1999, p.115.

10 Ficaram assim conhecidos, por analogia à influência que os instrutores alemães exerceram sobre os oficiais da Turquia. In: O Exército na História do Brasil, op.cit., p.74.Para exprimir suas idéias, os Jovens Turcos fundaram a Revista A Defesa Nacional cujo primeiro número,publicado em 1913, destacava ser o Exército um poderoso instrumento para a modificação de uma sociedadeatrasada, defendendo a manutenção de uma atitude apolítica por parte dos militares. In: HAYES, Robert A, op. cit., p.118. O grupo ameaçou posições estabelecidas no interior das Forças Armadas e foi por isso bastantehostilizado. 
O Primeiro Conflito Mundial, ao revisar o conceito tradicional de guerra, atingiria diretamente as Forças Armadas, conscientizando-as do obsoletismo bélico e tecnológico nacional.

Impunha-se a modernização. O Exército Francês vitorioso seria a força bélica escolhida para conduzir o processo. Atuando inicialmente nas Escolas de Formação, a Missão Francesa enfatizava a necessidade de se conhecer profundamente os problemas nacionais e o Exército, reflexo da Nação, corpo uno integrado pelo povo e pela bandeira, apresentava-se como a instituição republicana restauradora dos males tradicionais do regime ${ }^{11}$.

Internamente, a Primeira República agonizava. A campanha presidencial de 1922, palco de um novo incidente envolvendo os militares - uma carta falsa atribuída à Arthur Bernardes, candidato governista, ofendendo o Exército - constituiria-se no marco inicial de um ciclo de rebeliões, prenúncio de uma revolta maior, que sacudiram o país ao longo dos anos vinte, historicamente denominado de Movimento Tenentista ${ }^{12}$.

Combatido pelo próprio Exército como força legalista e anti-revolucionária, o tenentismo canalizou as aspirações de mudanças dos segmentos sociais descontentes, enfrentando os setores autoritários conservadores e influenciando a esquerda revolucionária.

Desafiadores, os “tenentes” protagonizariam em 1924 seu mais glorioso feito: a Coluna Prestes que, durante dois anos, adotando a tática da guerra de guerrilha, percorreu cerca de 25 mil quilômetros e atravessou 14 estados da Federação fazendo propaganda da revolução. Pretendiam os revolucionários a derrocada do regime e a implementação de reformas sociais.

A Coluna se dissolveria em 1927 com seus principais líderes exilando-se na Bolívia e Paraguai; não obstante, a República Velha chegava aos seus estertores.

11 A doutrina militar francesa recrudesceria, ainda mais, a mística militar.Um estudo pormenorizado sobre a Missão Francesa pode ser encontrado em: MAGALHÃES, João Batista, A evolução Militar do Brasil, Rio de Janeiro, Biblioteca do Exército, 1956, pp.349-360.

Inexistia, entretanto, hegemonia no interior do Exército. Três grupos ideologicamente distintos dividia a oficialidade: os jovens turcos, seguidores da corrente profissional e apolítica; o grupo dos oficiais do alto escalão inspirados em Caxias e, o grupo mais atuante, o dos jovens tenentes, defensores da superioridade institucional do Exército dentro do Estado.

12 Poppe de Figueiredo, um dos generais de 1964, ao falar sobre a revolta de 1922, afirmou: "aquela noite marcou o começo do ciclo revolucionário dos tenentes, que somente alcançou a vitória final em 1964". In: 
O episódio final desenrolar-se-ia na campanha eleitoral de 1929 com Getúlio Vargas, opositor do paulista Júlio Prestes, tendo sido derrotado em eleições fraudadas, fato que fez eclodir uma revolta no Rio Grande do Sul.

Era o fim da “política dos governadores” e o início da era Vargas.

b. O período de 1930 a 1945

A deposição de Washington Luiz pelos Comandantes das Forças Armadas e a instauração do governo provisório chefiado por Getúlio Vargas, encerram a Primeira República com a renovação dos dirigentes do Estado.

No quadro convulso vivenciado pela Nação, o Exército, confuso e dividido, uma vez que a maioria dos oficiais superiores não haviam participado da Revolução, cindiu-se em dois grupos ideologicamente divergentes: os reformistas, defensores da idéia de que países periféricos como o Brasil deveriam ser tutelados pela corporação, e, os apolíticos, de postura menos intervencionista, mas propugnadores do salvacionismo militar como solução para resgatar o Estado das ambições pessoais que o ameaçavam.

Impunha-se estabelecer a unidade no interior da Força e Vargas, com sua notável habilidade política, cooptaria os tenentes, dando-lhes promoções rápidas e cargos importantes no início do governo ${ }^{13}$. A participação dos tenentes na Revolução Constitucionalista de 1932 lutando ao lado do Governo Federal revela a importância daqueles atores políticos nos primórdios da Segunda República ${ }^{14}$.

HINSON Jr, William Jefferson, The military regime of Brazil: historical and ideological factors, tese de mestrado apresentada na Universidade de Columbia, Nova York, 1978, p.8

13 Líderes tenentistas como Juarez Távora, João Alberto e Juraci Magalhães, dentre outros nomes, ocupariam cargos de relevo na Administração federal e estadual. Neste sentido, José Murilo de Carvalho afirma que a crise nacional de 1930 eliminou a coalizão dos maiores estados da federação, fato que propiciou a estabilidade política e social, abrindo espaço para um maior desempenho das Forças Armadas no campo político. In: As Forças Armadas e a Política no Brasil - 1930-1945, Rio de Janeiro, Zahar, 1982, p.221.

14 "O projeto tenentista defendia medidas como a centralização do sistema tributário, o fortalecimento das Forças Armadas, a federalização das milícias estaduais, a criação de uma legislação trabalhista e a modernização da infra-estrutura do país. Do ponto de vista político, os "tenentes" aprovavam a centralização do poder nas mãos de Vargas e desconfiavam da representação partidária vista como palco para a atuação de grupos voltados apenas para os seus interesses privados. Isso significava defender a manutenção de um governo de caráter revolucionário e ditatorial e o adiamento do processo de constitucionalização. No entanto, naquele momento, a introdução de um regime de base constitucional era a principal reivindicação dos grupos oligárquicos, que se sentiam cada vez mais preteridos pelo governo e temiam o fortalecimento político dos “tenentes”. In: A Era Vargas. $1^{\circ}$ Tempo. Dos anos 20 a 1945, CD-ROM, Fundação Getúlio Vargas-CPDOC. 
Mas, a "guerra paulista”, aceleraria o processo de constitucionalização - a exemplo das eleições de 1933 para a Assembléia Nacional Constituinte - recompondo antigas alianças com os grupos oligárquicos regionais descontentes, o que acabou por provocar o alijamento dos tenentes do poder.

A compreensão da atuação dos militares na década de 30 passa, obrigatoriamente, pelo General Pedro Aurélio de Góes Monteiro, personagem proeminente da historiografia brasileira, cujas críticas e sugestões a propósito da reorganização do Exército durante a Revolta Constitucionalista mereceram a atenção de Vargas que o convidou para Ministro da Guerra.

Sua visão sobre as Forças Armadas era dicotômica. De um lado, o Exército se lhe afigurava uma instituição desorganizada e ineficaz, que necessitava de profissionalização, recrutamento e um sistema de promoções. De outro, considerava a corporação militar como a única instituição verdadeiramente nacional, de importância vital para a unidade do país. Concernente a arena política, defendia um governo forte e centralizador e a defesa da segurança interna pelos militares. Para ele, o Exército constituíase num órgão fundamentalmente político cuja responsabilidade era forjar uma consciência coletivista “de políticos do Exército e não de políticos dentro do Exército”15. O individualismo deveria ser suprimido de forma a assegurar a organização econômica e o progresso. Igualmente, deveriam ser asseguradas a justiça e a liberdade, valores compatíveis com a segurança nacional. As idéias de Góes Monteiro eram, pois, consoantes com o cooperativismo do Estado Novo varguista ${ }^{16}$.

15 GÓES MONTEIRO, Pedro Aurélio de, A Revolução de 30 e a Finalidade Política do Exército, Rio de Janeiro, 1937, p.181. Era conhecida a crítica de Góes Monteiro à influência positivista no Exército, para ele um fator de corrosão do espírito castrense. Aluno brilhante da Missão Francesa, seu treinamento reforçou o caráter profissionalizante das Forças Armadas e, na década de 30, por meio de sua ação, acabaria sendo implantado a idéia do profissionalismo militar a serviço da intervenção política.

16 Fato decisivo que contribuiria para que os Generais Góes Monteiro e Eurico Gaspar Dutra assumissem efetivamente o controle do Exército seria o fracasso da Intentona Comunista, organizada por Luiz Carlos Prestes em 1935, e o temor causado nos setores conservadores da sociedade. Houve um grande expurgo dentro dos quartéis e os dois generais, aproveitando-se da farsa de um suposto golpe integralista, deram apoio à Vargas para instaurar um regime de arbítrio - o Estado Novo - com o propósito de implementar no recém regime a política do Exército.

O Estado Novo era essencialmente um regime militar e, como tal, teve nas Forças Armadas seu principal sustentáculo. Segundo Edmundo Campos Coelho, neste período iniciou-se a institucionalização do Exército. Os tenentes foram cooptados e os extremistas expurgados após a Intentona de 1935 e o Golpe Integralista de 1938. Na Constituição de 1937, no capítulo referente às Forças Armadas, não constava a expressão "dentro dos limites da Lei”, ampliando-se a sua atuação no processo político decisório. In: Em Busca da Identidade:o Exército e a Política na Sociedade Brasileira, Rio de Janeiro, Forense Universitária, 1976, p.54. 
Por fim, a II Guerra Mundial aceleraria o processo de desenvolvimento brasileiro. Vargas e sua política pendular entre o Eixo e os Aliados acabou por escolher o lado certo, na hora certa. Sob o compromisso norte-americano de construir a Usina de Volta Redonda, o Brasil cedeu uma base aérea no Nordeste, estreitando as relações entre os dois Exércitos. A decisão de ingressar no conflito em 1942 fortaleceu ainda mais os laços de amizade e interesses entre as Forças Armadas dos dois Estados. A Força Expedicionária Brasileira (FEB), única grande unidade militar latino-americana a lutar na Europa, geraram reflexos e conseqüências intensas internamente. Os febianos, com a experiência adquirida junto aos americanos, puderam avaliar o atraso, sobretudo político, da Nação. Pressionado, Vargas promete eleições, mas em outubro de 1945 acabaria sendo deposto pelas Forças Armadas que, uma vez mais, seguindo o modelo moderador, devolveram o governo aos civis. Convocado novo pleito eleitoral, o General Dutra, candidato apoiado por Vargas, sai vitorioso, tendo como opositor o Brigadeiro Eduardo Gomes. A escolha de dois candidatos militares quis significar serem eles mais confiáveis do que os civis para conduzir o processo de transição ${ }^{17}$.

c. O Período de 1945 a 1950

A vitória da democracia na II Grande Guerra evidenciou a necessidade de o Brasil realinhar-se à nova conjuntura política mundial.

O período que compreende os anos de 1945 a 1950 caracterizou a transição do Estado Novo para a Terceira República. Eleições em 1945 deram a vitória à Dutra, apoiado por Vargas. Foi uma administração tranqüila, respaldada pela sociedade civil, sob a égide da qual promulgou-se a Constituição de 1946 de cunho liberalizante.

No Exército, a corporação dividia-se entre os nacionalistas ligados ao PTB e PSD e os internacionalistas que se identificavam com a UDN, integrando este último grupo os participantes da Força Expedicionária Brasileira que, visando alcançar uma posição de destaque no interior das Forças Armadas, criaram a Escola Superior de Guerra - ESG ${ }^{18}$.

17 Quanto ao golpe de 1945, esclareça-se que a iniciativa foi estimulada, mais uma vez, por grupos civis. Editoriais de jornais conclamavam os militares a exercer sua responsabilidade constitucional no restabelecimento da ordem jurídica e da legalidade, comprometidas com a continuação do presidente ditador.

18 O comandante da Artilharia da FEB, General Oswaldo Cordeiro de Faria, diria em entrevista a Alfred Stepan: "O impacto da FEB foi de tal natureza que, ao regressarmos ao Brasil, procuramos modelos de governo que funcionassem - ordem, planejamento, financiamento racional. Não encontramos este modelo no 
A doutrina da ESG associava os métodos de raciocínio cartesiano ensinados pela Missão Francesa, com as técnicas de planejamento aprendidas com os americanos durante a guerra. Seu projeto inicial consistia em analisar os problemas brasileiros dentro de um contexto global, priorizando a segurança nacional. Propunha, outrossim, a interação de grupos civis com os oficiais das Forças Armadas, modelo que seria decisivo para explicar a congruência de valores dos setores conservadores da sociedade e a intelligentzia militar na articulação e vitória do Golpe de 1964.

\section{d. O período de 1950 a 1964}

A candidatura de Vargas à presidência em 1950 teve como sustentáculo o trabalhismo e o nacionalismo. No seio das Forças Armadas os oficiais internacionalistas encararam-na com desconfiança, mas a ala nacionalista liderada pelo General Estillac Leal, Presidente do Clube Militar e mais tarde Ministro da Guerra, a apoiava.

Ao reverso do ocorrido no período ditatorial, Vargas acreditou não possuírem os militares condições efetivas para influírem na vida nacional. Com isto, o orçamento das Forças Armadas foi reduzido e Vargas voltou-se praticamente para o proletariado urbano. A primeira grande crise do segundo governo varguista eclodiria quando os militares lançaram o Manifesto dos Coronéis contra João Goulart, seu Ministro do Trabalho.

A infiltração de oficiais comunistas na ala nacionalista deu pretexto para que houvesse um expurgo no dispositivo militar, incluindo a exoneração de oficiais-generais de importantes comissões. Tais acontecimentos acabaram de inviabilizar a frágil sustentação política de Vargas pelas Forças Armadas.

Em 1954, seguida a forte campanha pela renúncia, Vargas suicida-se assumindo o governo o Vice-Presidente Café Filho. Nas eleições que se seguiram, Juscelino Kubitschek e João Goulart foram lançados pelo PSD e pelo PTB candidatos a Presidente e a Vice-Presidente, respectivamente, e tiveram como principal opositor um antigo tenente, Juarez Távora, indicado pela UDN e apoiado pela corrente neoliberal do Clube Militar. Os políticos udenistas, antigos opositores de Vargas, faziam apelos para que os militares interviessem no processo político mas, a maioria dos oficiais, defendia a postura legalista.

Brasil neste estágio, mas decidimos procurar meios de encontrar o caminho a longo prazo. A ESG era um meio para isto e ela medrou da FEB”. In:Os Militares na Política, op. cit., p.178. 
Vitorioso nas urnas, Kubitschek teria seu mandato ameaçado pela oposição udenista que sustentava a tese golpista de os candidatos não haverem obtido maioria absoluta dos votos. Julgado improcedente o pedido pelo Tribunal Superior Eleitoral, setores conservadores procurariam obstaculizar a posse dos eleitos.

Um grupo de oficiais liderados pelo próprio Ministro da Guerra, General Henrique Duflles Teixeira Lott, planejou, então, um contragolpe para dar garantir a legalidade e assegurar o "Retorno aos Quadros Constitucionais Vigentes.” Na noite de 11 de novembro de 1955, Lott não só deporia o Presidente em exercício Carlos Luz, como impediria o regresso de Café Filho - que se encontrava hospitalizado - entregando a chefia do Poder Executivo Federal ao Presidente do Senado, Nereu Ramos, que empossou Kubitscheck e Goulart.

O tempo que seguiu foi de grande turbulência nas Forças Armadas, com pequenas revoltas lideradas por oficiais da Aeronáutica. A cisão se acirrou com a campanha presidencial de 1960. Logo após a vitória de Jânio Quadros, candidato oposicionista, o novo Ministro da Guerra iniciou uma campanha de pacificação, transferindo os oficiais de esquerda para guarnições distantes do Rio de Janeiro, pondo fim a agitação no Clube Militar.

Com sua política contraditória, Jânio Quadros causava constrangimento nos meios militares. O golpe teatral da renúncia em 1961 revelar-se-ia uma impostura malograda que visava o recrudescimento do regime e a recondução do Presidente com poderes ditatoriais ${ }^{19}$.

O vice, João Goulart, em viagem à China, havia feito pronunciamento contra os militares revelando a intenção de estabelecer no Brasil uma República Sindicalista na qual a força de trabalho urbano substituiria a força militar como principal elemento de apoio ao governo $^{20}$.

19 Segundo Ricardo Maranhão, Jânio tinha basicamente três objetivos: primeiro, que os políticos, particularmente os da UDN, lhe concedessem poderes excepcionais; segundo, que as massas que haviam dado-lhe mais de cinco milhões de votos saíssem em sua defesa e, por último, que os militares o apoiassem com receio da figura "subversiva" de Goulart na Presidência, como seu substituto legal. O Estado e a Política Populista no Brasil (1954-1960), In: História Geral da Civilização Brasileira, Tomo III, O Brasil Republicano - Sociedade e Política (1930-1964), São Paulo, Difel, 1981, p.167.

20 Uma República Sindicalista não significava obrigatoriamente um regime comunista, contudo, o fato de os comunistas ocuparem cargos importantes no governo, inspirava o temor de que João Goulart realmente desejava implantar um regime de inspiração soviética. 
Os ministros militares opuseram-se à sua posse, fato que daria ensejo à primeira grande ruptura nas Forças Armadas com a insubordinação do III Exército no Sul do país e a ameaça de uma guerra civil.

O regime parlamentarista traduziu-se num rearranjo institucional para dar posse à João Goulart, que ao assumir a Chefia do Poder Executivo, envidaria todos os esforços para restaurar seus poderes presidenciais ${ }^{21}$. Inspirando-se no modelo varguista, governaria com o apoio do proletariado urbano e controlaria os militares com nomeações políticas. Promoveu e colocou em posições destaque os chamados "generais do povo", política que causaria sérios problemas ao seu governo, nomeadamente a quebra da hierarquia, bem ilustrada pelas Revoltas dos Sargentos e dos Marinheiros.

Ora, a hierarquia é o principal pilar de sustentação da estrutura militar e, os movimentos dos sargentos e marinheiros, romperam com a estrutura de comando. Eles passaram a agir como uma categoria social distinta, com interesses cooperativistas e políticos próprios, o que colocava em questão, pela a primeira vez na história brasileira, a possibilidade de uma mudança no estatuto de classe da burocracia militar ${ }^{22}$.

Os clubes militares fizeram manifestos contra a situação e oficiais legalistas não tinham mais argumentos para evitar a queda do Presidente. Apoiados por um forte esquema que reuniu os políticos, a igreja, a sociedade conservadora e a elite detentora dos meios de produção e financeira, em 31 de março de 1964, as Forças Armadas assumiriam o controle do Estado.

A compreensão do papel das Forças Armadas no período que permeia os anos de 1945 a 1964 passa, obrigatoriamente, pela Constituição de 1946 que, em seu artigo 177, dispunha sobre as funções da instituição militar na estrutura jurídico-política do Estado.

À semelhança do artigo 162 da Carta Constitucional de 1934, a Lei Fundamental de 1946 estabelecia;

Verbis:

21 O lapso temporal entre a renúncia de Jânio e a posse de João Goulart revelaria a divisão do poder estatal entre os militares e o Partido Social Democrático - PSD. Neste período ocorreu um deslocamento do centro decisório para a cúpula militar. Em contrapartida, restou evidente faltar aos militares um consenso para que, já em 1961, impusessem uma solução política impopular. Na verdade estava armado o cenário para uma crise ${ }_{22}$ que alcançaria seu desfecho em 1964. 
“Art. 177 - Destinam-se as Forças Armadas a defender a Pátria e a garantir os poderes constitucionais, a lei e a ordem”.

Referida preceituação atribuía claramente às Forças Armadas a função de árbitro - legal ou supra legal - entre os segmentos econômicos-sociais, sóciopolíticos e políticos, erigindo a cânon constitucional os interesses capitalistas e a ordem burguesa.

Da função moderadora decorria a função de intérprete da norma jurídica, cuja pretensão exegética consistia em determinar quem poderia exercer o poder e ter acesso ao aparelho de Estado. Dita regulação afetou profundamente a dinâmica política, sobretudo no que concernia aos partidos, vez que suas relações não estavam demarcadas por uma estrutura burocrática definida. Os mecanismos seletivos passaram a ser atribuição da instituição mantenedora da ordem: as Forças Armadas ${ }^{23}$. Neste sentido, detinham os militares o poder de caracterizar comportamentos, personalidades e soluções ameaçadoras ao regime, cabendolhes a última palavra sobre situações específicas. A ilegalidade do Partido Comunista em 1946 e as limitações sofridas pelo PTB, exemplificam a distorção estrutural do regime.

Esta situação anômala trouxe no seu bojo o germe da crise política ao longo de toda a transição do governo, constituindo um enorme incentivo para que as facções em luta pelo poder transbordassem os limites constitucionais e apelassem para o Golpe de Estado.

Concomitantemente, o cenário mundial da Guerra Fria alteraria profundamente o papel das Forças Armadas na conjuntura interna brasileira. Isto porque, a concepção de guerra sofreu uma total revisão após 1945, gerando o afastamento dos países subdesenvolvidos de um eventual conflito externo. Ora, tal afastamento surtiu um efeito vital sobre as Forças Armadas. Era a perda de sua função precípua. Criadas para uma guerra externa, a História mostra e a instituição pressentia, que um organismo residual pode durar, mas dura pouco e acaba descartado. Não tendo mais essência, não teria mais função. Daí a providência de ter-se atribuído às Forças Armadas a manutenção da ordem interna, a fim de legitimar sua existência ${ }^{24}$.

23 SILVA, Hélio, In: O Poder Militar, Rio Grande do Sul, L\&PM, Editores Ltda, 1984, p.29 ${ }^{23}$ WRIGHT, Erik Olin, Class, Crisis and the State, London, M.L.B, 1978, cap. IV. Ver, ainda, OFFE, Claus,Problemas Estruturais do Estado Capitalista, tradução de Bárbara Freitas, Rio de Janeiro, Tempo Brasileiro,1984, pp.140-177.

${ }_{24}$ Sobre a militarização da América Latina e do Brasil em específico, consultar: LAMOUNIER, Bolívar, Ideology and Authoritarian Regimes: theorical perspectives and a study of the brazilian case, Los Angeles, Tese de Phd apresentada à Universidade da Califórnia, 1974 (mimeog.); JANOWITZ, Morris, The 
A doutrina de segurança nacional, fruto da divisão do mundo em zonas de influência, estabelecida pelos Tratados de Yalta e Postdam, viria como resposta a um tipo de justificação: o avanço do comunismo soviético e a submissão do mundo à Rússia de Stalin.

A perpetuação do contexto bélico global incitou uma inversão perversa da fórmula de Clausewitz ao reduzir a política à continuação da guerra por outros meios. A guerra não mais se revestia do seu processo convencional, ela era "fria", "ideológica", processava-se em todos os campos, a todas as horas, a exigir vigilância constante e permanente; sobretudo porque, no seu conceito moderno, tinha lugar no interior do próprio Estado. Ela era "total" 25 e haveria de ser combatida com os mecanismos de defesa interna firmados pela doutrina da segurança nacional.

Professional Soldier, a Social and Political Portrait, Glencoe, The Free Press of Glencoe, 1960, LIMA JÚNIOR, Olavo Brasil, Intervenções Militares na América Latina, Rio de Janeiro, tese de mestrado apresentada ao IUPERJ, 1971, (mimeog).

25 Decorrem da interpretação de "guerra total" os conceitos de guerra generalizada, guerra fria, guerra revolucionária e guerra ideológica.

1) A guerra generalizada, parte do conceito extremamente ambíguo da Junta dos Chefes do EstadoMaior dos Estados Unidos, que a definia como: "o conflito armado entre grandes potências, na qual os recursos totais dos beligerantes são postos em ação, e na qual a sobrevivência de uma delas representa um perigo”. In: COMBLIN, Joseph, A Ideologia da Segurança Nacional, tradução de A. Veiga Fialho, Rio de Janeiro, Civilização Brasileira, 1978, 2ª ed., p.33. Justapondo tal definição à teoria de Ludendorff, segundo a qual a guerra é suprema expressão da vontade de viver de uma raça, a idéia de guerra total deve ser encarada como uma guerra pela sobrevivência. In: LUDENDORFF, Erich, Conduite de la Guerre et Politique, tradução L. Koeltz, Paris, Berger-Levrault, 1992, p.1. A guerra contra o comunismo era, pois, necessariamente, uma guerra pela sobrevivência, pela sobrevivência do Ocidente; é uma guerra absoluta, a demandar engajamento de todo o povo, absorvendo a política e fazendo-a desaparecer.

2) A guerra fria, foi a grande inovação. Suas formas eram novas, daí ser preciso combatê-la com uma estratégia adequada. Tratava-se de uma guerra permanente, travada em todos os planos - militar, político, econômico, psicológico - mas que evita o confronto armado. O ponto de partida para sua interpretação foi dado após a Segunda Guerra Mundial, pela Doutrina Truman, enunciada em 1947, segundo a qual o comunismo repete o nazismo. Assim, a segurança dos Estados Unidos se encontrava ameaçada em qualquer lugar onde o comunismo ameaçasse se impor aos povos livres. A Doutrina Truman visava diretamente à defesa da Europa contra uma real ou imaginária agressão russa e, no contexto do pós-guerra, atribuíram-lhe, rapidamente, certo valor de universalidade. Mas seria sob a Presidência de Eisenhower que esta doutrina ganharia plena formulação com os pactos de segurança coletiva, unindo 50 países da Ásia, Europa e América. Os Estados Unidos envolveriam, desta forma, o mundo comunista num cordão sanitário, criando uma "psicose de encarceramento", na expressão de Joseph Comblin.

3) Por fim, da idéia de guerra fria, extraiu-se a guerra revolucionária, cujo principal veículo de manobra era a guerra psicológica. Por este veio, e contando com o auxílio exterior, ela visava à conquista do poder pelo controle progressivo da Nação, utilizando formas de subversão e violência para impor a concepção marxistaleninista de Estado. Sobre a extensão de tais conceitos no Brasil, vide: Manual Básico da Escola Superior de Guerra, Rio de Janeiro, Estado Maior das Forças Armadas - Escola Superior de Guerra, 1977-1978, pp. 237 a 255; BRIGAGÃO, Clóvis, O Mercado da Segurança - Ensaios sobre economia política da defesa, Rio de Janeiro, Nova Fronteira, 1984; GURGEL, José Alfredo Amaral, Segurança e Democracia: uma reflexão política sobre a doutrina da ESG, Rio de Janeiro, Biblioteca do Exército, José Olímpio, 1975. 
As conseqüências da doutrina da segurança foram nefastas. Ela perpetrou a alteração da política tradicional e o aniquilamento de dissensões ao suprimir a diferença entre os meios de pressão violentos e não violentos, permitindo-se obter a segurança por ambas as formas ou, pior ainda, destruindo as barreiras das garantias constitucionais; isto, no âmbito interno. No plano externo, significou a extinção da fronteira entre a guerra e a diplomacia. Ademais, esta doutrina desfez a distinção entre política externa e política interna. O inimigo estava ao mesmo tempo dentro e fora do país. O Exército passou a atuar como força "policialesca", a medida que a "guerra" ganhava unicidade. E, finalmente, a segurança nacional igualou a violência preventiva à repressiva.

Esta estratégia dissolvente, cujo objetivo a longo prazo foi a desmoralização das instituições liberais e o afastamento popular do processo de organização do poder, reforçou a intervenção militar, a condução do Estado pelas classes dominantes e a união multinacional $^{26}$.

O Ato Institucional de 9 de abril de 1964 selaria juridicamente o fim da Terceira República que, sob o aspecto político, já fora derrubada de fato dez dias antes pelo movimento armado de 31 de $\operatorname{março}^{27}$, coroando o início de um sistema de governo despótico, fadado a durar vinte anos.

Sua edição mudou o cenário nacional. A implicação era evidente: a política de compromisso tinha sido desacreditada pelo jogo "ultrademocrático" de Goulart. A

${ }^{26}$ Numa análise mais apurada, observa-se que a "Doutrina da Segurança Nacional” contém uma identificação espantosa com a "Doutrina Positivista" tal qual fora concebida no Brasil. Como ocorreu na República Velha, repetindo-se em 1964, a linha de interpretação e construção ideológica de ambas as doutrinas visaram respaldar uma distinção de classes. A necessidade de uma "República ditadorial" em 1890, ou de um "Estado autoritário" em 1964, revelava-se como condição para se efetivar a "ordem e progresso" ou a "segurança e o desenvolvimento", sem perturbações sociais. Afinal, segundo Comte, "o progresso é o desenvolvimento da ordem, assim a ordem é a consolidação do progresso", o que significa que não se podem romper, subitamente, os laços com o passado e que toda reforma, para frutificar, deve tirar seus elementos da própria situação vigente a ser modificada. In: LINS, Ivan, História do Positivismo no Brasil, São Paulo, Companhia Editora Nacional, 1964, p.337.

27 Na interpretação de Skidmore, "este Ato do Supremo Comando Revolucionário era uma resposta nova à crise de autoridade política que se evidenciava no Brasil desde os meados da década de 50. Quadros tinha se queixado de que lhe faltavam poderes adequados para lidar com o Congresso. Goulart repetira a queixa, chegara a propor um Estado de Sítio em outubro de 1963 e, em princípios de 1964, apresentara diversas propostas específicas para fortalecer o braço do Executivo. O Ato Institucional era, pois, nova e decisiva resposta à manifesta incapacidade do Executivo Brasileiro de exercer a necessária autoridade (...)”. In: SKIDMORE, Thomas, Brasil: de Getúlio a Castelo, Rio de Janeiro, Paz e Terra, 1976, 5 a ed., p.373. 
intervenção do Exército era um retorno à mensagem autocrática apregoada por Jânio Quadros responsabilizando os "políticos" pela condução do Brasil ao caos²8.

Profundamente descaracterizada, a Carta de 1946 teria uma sobrevida formal que se dilatou até a promulgação da Constituição de 24 de janeiro de 1967. Mas, a partir do primeiro Ato Institucional, ela não passaria de uma sombra ou fantasma de Constituição.

\section{O REGIME MILITAR DE 1964}

O golpe de Estado perpetrado em 1964, nos seus primórdios, resultou mais de uma conexão existente entre a sorbonne brasileira haurida na Escola Superior de Guerra, com o empresariado clientelista, a tecnoburocracia, os grandes proprietários rurais e urbanos, os cartéis multinacionais e a classe média tradicional que tinha a grande imprensa como porta-voz do que, propriamente, de um movimento conspiratório militarcorporativista, sem qualquer ligação com a sociedade civil $^{29}$.

Isto se vê claro em agosto de 1961, quando os ministros militares, na tentativa de impedir a posse do vice-presidente eleito João Goulart, agindo pro domo suae, à inteira revelia das forças populares e mesmo das classes conservadoras, colheram um rotundo fracasso político-militar, dado o isolamento do putsch circunscrito, unicamente, ao estamento.

Colocando no patamar devido a participação dos militares nos eventos de 1964 e os desdobramentos inevitáveis que se lhe seguiram no chamado ciclo dos militares no poder, deve-se considerar a conjugação de interesses entre a facção militar das Forças Armadas Brasileiras ligadas à ESG - não necessariamente majoritária, mas, plenamente atuante e articulada - e os setores organizados do capital e da tecnoburocracia civil, que viam no avanço populista de Goulart um obstáculo aos projetos de segurança nacional que se julgavam avalistas.

\footnotetext{
28 Idem, p. 373.

29 Mesmo o movimento de retrocesso político ocorrido em 1937, não passou de mera projeção militar, resultado de articulações políticas da sociedade conservadora interessada na preservação do status quo, do que na tentativa de afirmação e estabelecimento de um Estado militarista.

Neste sentido consultar, DREIFUSS, René Armand, 1964- A Conquista do Estado: ação política, poder e golpe de classe, tradução do Laboratório de tradução da Universidade Federal de Minas Gerais, Petrópolis,

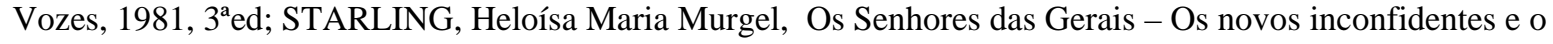


Surpreende a inexistência de um plano único de conspiração visando a tomada do poder. Enquanto o General Carlos Luiz Guedes atribuía às forças militares sediadas em Minas Gerais a responsabilidade pelo início da sublevação, Armando Falcão, Ministro da Justiça no Governo Geisel, ressaltava o general Humberto Castelo Branco como figura central que coordenou a ação no alto comando contra o governo deposto.

De igual modo, adesões de última hora ao movimento como as dos Generais Costa e Silva, Justino Alves Bastos, Amaury Kruel, Floriano Machado e outros são consideradas, ora importantes e decisivas, ora irrelevantes e puramente oportunistas, segundo as preferências e o ângulo de observação dos historiadores e analistas.

O certo é que a vitória de 1964 revelou a ausência de um projeto de poder militar, como de resto, não vislumbraram os grupos militares esquerdistas nacionalistas que gravitam em torno de João Goulart, qualquer estratégia articulada de governo.

Evidente, pois, no processo histórico brasileiro - ao reverso do ocorrido na América Latina -a incapacidade das Forças Armadas de moldar uma institucionalidade exclusivamente militarista. E isto por uma razão elementar, o Exército, Marinha e Aeronáutica do Brasil, composto pelos mais variados estratos sociais, não constituem uma classe social propriamente dita. Pertencendo seus integrantes às várias camadas da população, tornavam-se permeáveis às motivações ideológicas de natureza de classe ou política, em confronto com os princípios da hierarquia e da disciplina, base da organização castrense.

Como instituição permanente, qualquer tentativa de aliciamento da tropa e da oficialidade com objetivos políticos esbarram na formação espartana, que é o sentido de sua profissionalização. Mas, como parte integrante do povo, não está imune às suas lutas e aspirações.

Dito axioma prova que, a despeito de terem tido papel saliente em 1964, não foram os militares os únicos e exclusivos responsáveis pelo establishment que se criou. Conquanto decisiva sua participação, tiveram papel coadjuvante, quiçá secundário, sem embargo de mantenedores da ordem autocrática.

Desta maneira, o sonho tenentista de uma modernização conservadora executada por um Estado despolitizado somente iria perdurar até esgotar-se a junção de golpe de 1964, Petrópolis, Vozes, 1986, 2aed e ROCHA, Maria Elizabeth Guimarães Teixeira, O Processo 
interesses da elite orgânica e das Forças Armadas na condução do Estado. E, neste momento, os militares - fiadores da ordem autoritária - foram excluídos da dinâmica política, por terem se tornado aliados incômodos de uma elite já reforçada em seu poder hegemônico.

\section{CONCLUSÃO}

Muito tem-se discutido porque somente em 1964 os militares, após realizarem diversas intervenções na ordem constitucional brasileira, resolveram perpetuarem-se no poder, abandonando a antiga posição de devolvê-lo à classe política.

Em geral, os governos necessitam estabelecer planos dirigentes. O projeto militar consistia na superação da heterogeneidade e na obtenção da homogeneidade. Para tanto, o desenvolvimento econômico impunha-se como fator fundamental, ressalvadas as condições de segurança essenciais para sua implementação ${ }^{30}$. Tendo como suporte estratégico-ideológico a doutrina de segurança nacional, as Forças Armadas tentaram empregar os princípios organizativos da instituição militar no reordenamento do Estado Brasileiro $^{31}$.

Ocorreu, contudo, que o projeto militar brasileiro, nunca explicitado pelas Forças Armadas, só alcançou um nível razoável de articulação no início dos anos 60. Tendo como meta principal a implantação de mudanças significativas na sociedade brasileira, sua discussão sempre foi evitada, pois levaria as diversas correntes de pensamentos existentes nas Forças Armadas a entrarem em conflito, o que acarretaria na perda do consenso.

Os temas que no período de 1963 a 1964 uniram os militares e permitiram alcançar um alto grau de coesão foram o anticomunismo, a anticorrupção e a idéia de que a organização militar estaria ameaçada pela República Sindicalista de Goulart. Logo após 31 março de 1964, muitos oficiais temiam que o debate sobre temas nacionais provocasse

Político no Brasil. Estado e classes sociais, op. cit.

30 HAYES, Robert A., Nação Armada. A mística militar brasileira, op. cit., p.224.

31 Havia uma nítida ligação entre o projeto militar pós 64 com o Estado Novo. Basta ver que o Primeiro Ato Institucional foi preparado por Francisco Campos, mentor da Constituição de 1937. As idéias de Góes Monteiro seriam revividas. "Ajustavam-se às circunstâncias o conceito de que o Exército era um órgão essencialmente político, ao qual interessavam todos os aspectos da verdadeira política nacional e a idéia de que "um exército bem organizado é o instrumento mais poderoso de que dispõe um governo para a educação do povo, para a consolidação do espírito nacional e para a neutralização das tendências dispersivas." Idem, p.225. (grifos no original) 
cisões dentro do movimento. Na confusão que se seguiu aos primeiros dias do golpe, os chefes militares e civis voltar-se-iam para o único grupo que tinha idéias para governar o país: Castelo Branco e os oficiais da ESG.

Efetivamente, em 1964 surgiria a grande oportunidade de irradiação da doutrina "esgiana” pois, apesar de inexistir um projeto acabado de administração do Estado, o grupo de oficiais e tecnocratas civis oriundos da Escola Superior de Guerra, haviam recebido uma formação comum sobre os problemas nacionais. Pairava no seio das Forças Armadas um elevado clima de expectativa de serem seus integrantes os mais preparados para o exercício do governo; idéia reforçada por segmentos civis da sociedade que partilhavam os mesmos pontos de vista dos militares.

Mas, o regime implantado em 1964, descortinaria problemas idênticos aos dos regimes civis. Embora tenha ocorrido um considerável desenvolvimento social e econômico, os desequilíbrios regionais, a pobreza, o analfabetismo e a corrupção, acabariam por demonstrar a falácia da mística militar e o fracasso de uma utopia que não se concretizou.

\section{REFERÊNCIAS}

A Era Vargas. $1^{0}$ Tempo. Dos anos 20 a 1945, CD-ROM, Fundação Getúlio VargasCPDOC.

DREIFUSS, René Armand, 1964- A Conquista do Estado: ação política, poder e golpe de classe, tradução do Laboratório de tradução da Universidade Federal de Minas Gerais, Petrópolis, Vozes, 1981, $3^{\mathrm{a} e d .}$

FINER, Samuel. In: The military in politics of today in comparative government, editado por Jean Blondel, Nova York, The Macmillan Press, 1982,

GÓES MONTEIRO, Pedro Aurélio de, A Revolução de 30 e a Finalidade Política do Exército, Rio de Janeiro, 1937

HAYES, Robert A, Nação Armada - A mística militar brasileira , tradução de Delcy A. Doubrawa, Rio de Janeiro, Biblioteca do Exército, 1991.

HINSON Jr, William Jefferson, The military regime of Brazil: historical and ideological factors, tese de mestrado apresentada na Universidade de Columbia, Nova York, 1978. 
HUNTINGTON, Samuel. In: The soldier and the state: the theory and politics of civilmilitary relations, Cambridge, Mass, Harvard University, 1957.

JANOWITZ, Morris, The Professional Soldier, a Social and Political Portrait, Glencoe, The Free Press of Glencoe, 1960.

. Military Institutions and Coercion in Developing Countries, Chicago, University of Chicago Press, 1977.

LAMOUNIER, Bolívar, Ideology and Authoritarian Regimes: theorical perspectives and a study of the brazilian case, Los Angeles, Tese de Phd apresentada à Universidade da Califórnia, 1974 (mimeog.).

LIMA JÚNIOR, Olavo Brasil, Intervenções Militares na América Latina, Rio de Janeiro, tese de mestrado apresentada ao IUPERJ, 1971, (mimeog).

LOWENTAL, Abraham F., Armies and Politics in Latin America, New York, Holmes \& Meier Publishers, Inc., 1976.

MAGALHÃES, João Batista, A evolução Militar do Brasil, Rio de Janeiro, Biblioteca do Exército, 1956.

NUM, José. The midlle class military coup. In: The politics of conformity in Latin América, editado por Cláudio Veliz, London, Oxford University, 1970.

O Exército na História do Brasil, Rio de Janeiro, Biblioteca do Exército Ed. 1998, V.3, p.12.

O’DONNELL, Guilhermo. In: Modernización y autoritarismo, Buenos Aires, Paidos, 1972.

OFFE, Claus, Problemas Estruturais do Estado Capitalista, tradução de Bárbara Freitas, Rio de Janeiro, Tempo Brasileiro,1984.

OLIVEIRA FREIRE, Felisbelo de, História Constitucional da República dos Estados Unidos do Brasil, Brasília, Editora Universidade de Brasília, 1983.

OLIVEIRA TORRES, João Camilo de, O Positivismo no Brasil, Petrópolis - Rio de Janeiro - São Paulo, Vozes, 1943.

ROCHA, Maria Elizabeth Guimarães Teixeira, O Processo Político no Brasil. Estado e Classes Sociais, Belo Horizonte, Del Rey, 1999. 
SILVA, Hélio, In: O Poder Militar, Rio Grande do Sul, L\&PM, Editores Ltda, 1984.

SKIDMORE, Thomas, Brasil: de Getúlio a Castelo, Rio de Janeiro, Paz e Terra, 1976, $5^{\text {a }}$ ed.

STARLING, Heloísa Maria Murgel, Os Senhores das Gerais - Os novos inconfidentes e o golpe de 1964, Petrópolis, Vozes, 1986, $2^{\text {a ed }}$

STEPAN, Alfred. Os Militares na Política, Rio de Janeiro, Ed. Arte Nova, 1975.

WRIGHT, Erik Olin, Class, Crisis and the State, London, M.L.B, 1978, cap. IV. 